\title{
The measurement of total body water in living pigs by deuterium oxide dilution and its relation to body composition
}

\author{
By R. A. HOUSEMAN, I. McDONALD aNd K. PENNIE \\ Rowett Research Institute, Bucksburn, Aberdeen $A B 2{ }_{9} S B$
}

(Received 27 November 1972 - Accepted 9 February 1973)

\begin{abstract}
I. Deuterium oxide was used to estimate body water in twenty-four pigs of widely differing body composition and of average weight $83.9 \mathrm{~kg}$.

2. After infusion of the isotope, blood samples were collected every $30 \mathrm{~min}$ for $4 \mathrm{~h}$. The resulting plasma was purified by a heat-distillation procedure, after which it was analysed for $\mathrm{D}_{2} \mathrm{O}$ by infrared spectroscopy.

3. Approximately $24 \mathrm{~h}$ after infusion of the $\mathrm{D}_{2} \mathrm{O}$ each pig was killed, and its composition determined both by chemical analysis and physical dissection.

4. Equilibration of $\mathrm{D}_{2} \mathrm{O}$ in the body was found to be complete within $2 \mathrm{~h}$ of injection of the tracer.

5. The mean $\mathrm{D}_{2} \mathrm{O}$ space was found to be $8.6 \%$ greater than the mean empty body water space, but only $2 \cdot 2 \%$ greater than the total body water space.

6. Empty body water and total body water were estimated from the regression lines with residual standard deviations of $2 \cdot 7$ and $1.9 \%$ respectively. Similarly, the residual standard deviations of the regressions involving the other fat-free components were $6 \cdot 3 \%$ for dissectible lean, $3.2 \%$ for fat-free mass, and $5.6 \%$ for crude protein.

7. The residual standard deviations of the regressions in which the weights of dissectible fat and total body lipid were predicted were 6.0 and $6.7 \%$ respectively.
\end{abstract}

The naturally occurring non-radioactive isotope of water, deuterium oxide $\left(\mathrm{D}_{2} \mathrm{O}\right)$ has been frequently used to estimate body water in several species because it is considered, as is tritium, to be an ideal test solute for measuring body water.

It has been used extensively in human subjects (Schloerb, Friis-Hansen, Edelman, Solomon \& Moore, 1950; Edelman, Olney, James, Brooks \& Moore, I952; Bradbury, 1961; Hytten, Thomson \& Taggart, 1966), but in farm animals there have been very few investigations in which $\mathrm{D}_{2} \mathrm{O}$ has been used. This is presumably because of the high cost and because specialized equipment is required to measure $\mathrm{D}_{2} \mathrm{O}$ concentrations.

$\mathrm{D}_{2} \mathrm{O}$ has been used for estimating body fat in pregnant Blackface ewes (Foot \& Greenhalgh, 1970). This study is of particular interest because a heat distillation technique (Turner, Neely \& Hardy, I960) was used for purifying the samples, which were then analysed by infrared spectroscopy (Stevens \& Thurston, 1954). These are relatively simple procedures compared with the vacuum distillation technique (Schloerb, Friis-Hansen, Edelman, Sheldon \& Moore, 1951) for purifying the samples and the falling drop method for determining the $\mathrm{D}_{2} \mathrm{O}$ concentrations (Hytten, Taggart, Billewicz \& Jason, 1962).

Groves \& Wood ( 1965$)$ working with suckling pigs used $\mathrm{D}_{2} \mathrm{O}$ for estimating changes in total body water (TBW). The relationship between $\mathrm{D}_{2} \mathrm{O}$ and TBW was fairly close $(r=0.8185)$, but it was found that $\mathrm{D}_{2} \mathrm{O}$ slightly underestimated TBW. The 
Table r. Composition of the diets

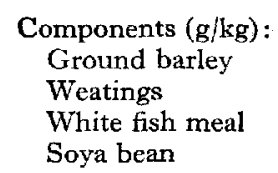

Supplements (g/kg main ingredients) :

Limestone

Dicalcium phosphate

Salt

Vitamin-mineral mixture*

Cyanocobalamin (mg)
$135 \mathrm{~g}$ crude protein $/ \mathrm{kg} \quad 220 \mathrm{~g}$ crude protein $/ \mathrm{kg}$ air-dry diet air-dry diet

$\begin{array}{rr}920 & 620 \\ 40 & 190 \\ 20 & 96 \\ 20 & 94\end{array}$

$\begin{array}{rl}6 \cdot 7 & - \\ 10 \cdot 0 & - \\ 1 \cdot 0 & - \\ 2 \cdot 2 & 2 \cdot 2 \\ 0.1 & -\end{array}$

* Isaac Spencer and Co. (Aberdeen) Ltd; Parkhill No. 2, providing per kg complete diet:

$\begin{array}{lrlr}\text { Vitamin A } & 660 \mu \mathrm{g} & \text { Zinc } & \text { roo mg } \\ \text { Cholecalciferol } & 15 \mu \mathrm{g} & \text { Magnesium } & \text { 10 mg } \\ \text { Riboflavin } & 2 \mathrm{mg} & \text { Manganese } & 30 \mathrm{mg} \\ \text { Cyanocobalamin } & 5 \mu \mathrm{g} & \text { Iron } & 60 \mathrm{mg} \\ \text { Calcium pantothenate } & 10 \mathrm{mg} & \text { Cobalt } & 0.9 \mathrm{mg} \\ \text { Nicotinic acid } & 10 \mathrm{mg} & \text { Iodine (stabilized) } & 1 \cdot 0 \mathrm{mg} \\ \text { Copper } & 200 \mathrm{mg} & & \end{array}$

authors concluded that this was possibly due to the slow equilibration of $\mathrm{D}_{2} \mathrm{O}$ with the water in the bladder.

$\mathrm{D}_{2} \mathrm{O}$ dilution studies have not been undertaken in older pigs, and the object of the experiment to be described here was to make estimates of TBW in $90 \mathrm{~kg}$ pigs, which differed widely in fatness, and to relate these to various measurements of body composition made by subsequent carcass analysis.

\section{EXPERIMENTAL}

\section{Animals and diets}

Twenty-four Large White $\times$ (Large White $\times$ Landrace) pigs were used which were obtained from the Institute's hysterectomy-derived pig herd. The group consisted of twelve castrated males and twelve females which had been reared at different rates from 25 to $90 \mathrm{~kg}$. The treatments were combinations of increasing daily feed intake $\left(70-140 \mathrm{~g} / \mathrm{kg}^{0 \cdot 75}\right.$ ) with two dietary protein concentrations ( $\mathrm{I} 35$ and $220 \mathrm{~g}$ crude protein $/ \mathrm{kg}$ ) and were intended to promote large differences in body fatness. The compositions of the diets are given in Table $\mathrm{I}$.

\section{Housing and management}

The pigs were weaned at 6 weeks of age and creep feed was available for a further 2 weeks. At 8 weeks the pigs were given a standard diet containing $170 \mathrm{~g}$ crude protein/kg. At $25 \mathrm{~kg}$ live weight each pig was transferred to a piggery with a controlled environment. Here they were housed individuaily and fed twice daily. Increments of feed intake were made for each pig every $7 \mathrm{~d}$ after they had been weighed. The pigs were weighed at the same time each week in order to minimize the variation in the 
intestinal contents. When each pig approached $90 \mathrm{~kg}$ live weight it was given a standard intake of feed for $7 \mathrm{~d}$ in order to reduce variation in intestinal contents.

\section{Management of the pigs during the in vivo study}

Immediately before each pig was confined to a metabolism cage it was weighed. It was then deprived of food and water for about $\mathrm{I} 2 \mathrm{~h}$ before the administration of $\mathrm{D}_{2} \mathrm{O}$.

In order to obtain frequent and uncontaminated blood samples the venous catheterization method described by Anderson \& Elsley (1969) was used.

\section{Injection of $\mathrm{D}_{2} \mathrm{O}$ into the blood-stream}

$\mathrm{D}_{2} \mathrm{O}$ which had a minimum purity of $99.7 \%$ (Koch-Light Laboratories) was infused into the blood-stream of each pig as a saline solution $(9 \mathrm{~g} \mathrm{NaCl} / 1)$ using a Watson-Marlow peristaltic pump. The dose rate was about $\mathrm{g}_{2} \mathrm{O} / \mathrm{kg}$ body-weight. The rate of infusion was about $12 \mathrm{ml} / \mathrm{min}$. Immediately before and after infusion, the $\mathrm{D}_{2} \mathrm{O}$ container was weighed to the nearest $0.005 \mathrm{~g}$ and heparinized saline solution (Ioo i.u. sodium heparin $+9 \mathrm{mg} \mathrm{NaCl} / \mathrm{ml}$ ) was pumped into the system.

\section{Sampling of body fuids}

In a preliminary trial it was found that equilibration of $\mathrm{D}_{2} \mathrm{O}$ in the body was virtually complete within $2 \mathrm{~h}$ of injection of the tracer. In the present experiment, therefore, blood samples were collected, every $30 \mathrm{~min}$, in heparinized containers (Beckton Dickinson Ltd, Rutherford, New Jersey, USA) from each pig up to $4 \mathrm{~h}$ after injection. Each blood sample was immediately centrifuged at $1000 \mathrm{~g}$ for $\mathrm{I} 5 \mathrm{~min}$ and the resulting plasma decanted into air-tight vials and stored at $x^{\circ}$ to await analysis.

Urine and faeces voided during the equilibration period were not collected because it had been found in preliminary trials that these were difficult to purify and analyse.

\section{Estimation of $\mathrm{D}_{2} \mathrm{O}$ in body fluids}

The estimation of $\mathrm{D}_{2} \mathrm{O}$ in biological fluids involves $(a)$ the purification of the sample without isotopic fractionation, (b) the estimation of $\mathrm{D}_{2} \mathrm{O}$ in the resulting $\mathrm{D}_{2} \mathrm{O}$-water mixture.

In this experiment the plasma samples were purified by means of a heat-distillation method (Turner et al. 1960). $\mathrm{D}_{2} \mathrm{O}$ was estimated in the purified samples by means of infrared spectroscopy (Pye Unicam SP 200). The basis of this method is that the absorption of infrared radiation at a wavelength of $4000 \mathrm{~nm}$ by a distilled-water- $\mathrm{D}_{2} \mathrm{O}$ mixture is compared with that of a distilled-water reference solution. A series of standards was constituted in the range $0.5-2.5 \mathrm{ml} \mathrm{D}_{2} \mathrm{O} / 1$, and each unknown was compared against two standards of higher and lower concentrations. The concentration of $\mathrm{D}_{2} \mathrm{O}$ in each unknown was calculated from the expression used by Foot \& Greenhalgh (1970).

\section{Slaughter of the animals and subsequent processing}

Each pig was killed approximately $28 \mathrm{~h}$ after the $\mathrm{D}_{2} \mathrm{O}$ infusion. It was suspended by the hind legs and weighed on a steelyard to the nearest $20 \mathrm{~g}$. The major blood 
vessels of the neck were cut and each carcass was bled as fully as possible, and the weight of blood was recorded.

The carcass was then cut down the mid-ventral line and the entire alimentary tract removed, weighed, emptied and reweighed. The intestinal contents were homogenized and sampled for the estimation of dry matter.

After the hair had been removed by electric clippers, the carcass was divided into three parts, so that both physical dissection and chemical analysis could be facilitated. The three carcass divisions were designated middle, left side and right side.

The middle of the carcass included the head, backbone, blood, flare fat, internal organs and the entire alimentary tract. The left side of the carcass was stoted horizontally in a doubly-sealed polyethylene bag for $16 \mathrm{~h}$ at $\mathrm{I}^{\circ}$, after which it was physically dissected into skin + subcutaneous fat, lean and bone.

The right side of the carcass was jointed into pieces weighing approximately $7 \mathrm{~kg}$. These were stored at $-25^{\circ}$ in doubly-sealed polyethylene bags, as were the other portions of the carcass. After $5 \mathrm{~d}$ they were allowed to thaw and each component was removed from the polyethylene bag, weighed and then minced. The mince was mechanically mixed and then sampled. About I $\mathrm{kg}$ of the homogeneous mince from each of the three carcass divisions was used for chemical analysis.

\section{Estimation of $\mathrm{D}_{2} \mathrm{O}$ space}

Estimates of the $\mathrm{D}_{2} \mathrm{O}$ space of each pig were made from the equilibrium plasma $\mathrm{D}_{2} \mathrm{O}$ concentration. The equilibrium plasma $\mathrm{D}_{2} \mathrm{O}$ concentration was calculated from the mean of three plasma values obtained between 2 and $3 \mathrm{~h}$ after injection of the isotope. The equation was

$$
\mathrm{D}_{2} \mathrm{O} \text { space }(\mathrm{g})=\frac{\text { weight of solution injected }(\mathrm{g}) \times \mathrm{D}_{2} \mathrm{O} \text { concentration in solution }(\mathrm{g} / \mathrm{g})}{\text { equilibrium concentration in body fluid }(\mathrm{ml} / \mathrm{ml})} \text {. }
$$

\section{RESULTS}

Body composition of the pigs

Table 2 shows the mean values for each of the measurements that were made and the extent to which these measurements varjed over the twenty-four animals. The animals were all approximately of bacon weight but varied considerably in body composition. Despite the precautions that had been taken, there was substantial variability in gut fill, intestinal water, and bladder water. Apart from these, the greatest coefficients of variation were those relating to lipid content. The composition of the fat-free material was relatively constant.

On dissection it was found that the mean difference in weight between the two sides of the carcass was $0.48 \mathrm{~kg}$, the maximum being $\mathrm{r} \cdot 8 \mathrm{o} \mathrm{kg}$. The losses which occurred during the dissection of the left-hand sides were small (mean value $\mathrm{r} \cdot 6 \%$, standard deviation $1.0 \%$ of the side weight) and these were assumed to be entirely of water. These losses were accounted for in the calculation of body water by subtracting the weight of dry matter from the weight of the entire body minus the weights of intestinal and bladder contents (i.e. weight of empty body water (EBW) = empty body-weight - weight of dry matter). 
Table 2. Body composition of the pigs

(Mean values and standard deviations)

\begin{tabular}{|c|c|c|c|}
\hline Measurement & $\begin{array}{l}\text { Mean } \\
\text { value }\end{array}$ & SD & $\begin{array}{c}S D \text { as } \\
\text { percentage } \\
\text { of mean }\end{array}$ \\
\hline \multicolumn{4}{|l|}{ From physical dissection $(n=24)$ : } \\
\hline Live wt $(\mathrm{kg})$ & 83.9 & $5 \cdot I$ & 6.I \\
\hline Gut fill (kg) & $2 \cdot 7$ & 0.74 & $27 \cdot 4$ \\
\hline Water in bladder $(\mathrm{kg})$ & 0.5 & 0.9 & 180 \\
\hline Empty body-wt (kg) & 80.6 & $4 \cdot 6$ & $5 \cdot 7$ \\
\hline Dissectible fat (kg) & $17 \cdot 7$ & $3 \cdot 4$ & $19 \cdot 2$ \\
\hline Dissectible fat-free mass $(\mathrm{kg})$ & 6.8 & 4.8 & $7 \cdot 8$ \\
\hline Dissectible lean (kg) & $34 \cdot 6$ & $3 \cdot 5$ & $10 \cdot 1$ \\
\hline \multicolumn{4}{|l|}{ From chemical analysis $(n=24)$ : } \\
\hline Total body water $(\mathrm{kg})$ & $47 \cdot 6$ & $4 \cdot 8$ & 10.1 \\
\hline Empty body water (EBW) (kg) & 44.9 & $4 \cdot 3$ & $9 \cdot 6$ \\
\hline Water in intestinal tract $(\mathrm{kg})$ & $2 \cdot 2$ & 0.7 & $32 \cdot 7$ \\
\hline Total lipid $(\mathrm{kg})$ & $2 \pi \cdot 2$ & 4.7 & $22 \cdot 2$ \\
\hline Fat-free mass (FFM) (kg) & 59.4 & 5.8 & 9.8 \\
\hline Fat-free dry matter (FFDM) (kg) & $14 \cdot 5$ & $1 \cdot 6$ & II.0 \\
\hline Crude protein $(\mathrm{CP})(\mathrm{kg})$ & $12 \cdot 0$ & $r \cdot 3$ & 10.8 \\
\hline Ash $(\mathrm{kg})$ & $2 \cdot 5$ & 0.3 & $12 \cdot 0$ \\
\hline Lipid (g/kg empty body-wt) & 263 & $56^{2}$ & $21 \cdot 3$ \\
\hline Ratio EBW:FFM & 0.756 & 0.0096 & $1 \cdot 3$ \\
\hline CP:FFM & 0.201 & 0.0073 & 3.6 \\
\hline CP:FFDM & 0.826 & 0.012 & $\mathbf{I} 5$ \\
\hline Ash:FFDM & 0.173 & 0.0062 & $3 \cdot 6$ \\
\hline \multirow{2}{*}{\multicolumn{4}{|c|}{ From deuterium oxide determinations $(n=24)$ : }} \\
\hline & $48 \cdot 7$ & $4 \cdot 8$ & $9 \cdot 8$ \\
\hline
\end{tabular}

Table 3. Regression equations for estimating, in pigs, empty body water, total body water, and other components of the body, other than fat, from $\mathrm{D}_{2} \mathrm{O}$ space

\begin{tabular}{|c|c|c|c|c|}
\hline \multirow[b]{2}{*}{$\begin{array}{l}\text { Body component } \\
(\mathrm{kg})\end{array}$} & \multicolumn{4}{|c|}{ Regression equation on $\mathrm{D}_{2} \mathrm{O}$ space $(\mathrm{kg})$} \\
\hline & Coefficient & Intercept & RSD & $\begin{array}{c}\text { RSD as } \\
\text { percentage } \\
\text { of mean }\end{array}$ \\
\hline Empty body water & 0.869 & $+2 \cdot 6$ & $I \cdot 2 I$ & $2: 7$ \\
\hline Total body water & 0.989 & -0.5 & 0.89 & $I \cdot 9$ \\
\hline Dissectible fat-free mass & 0.955 & $+\mathrm{r} 5 \cdot 4$ & $\mathrm{I} \cdot 67$ & $2 \cdot 7$ \\
\hline Dissectible lean & 0.596 & +0.6 & $2 \cdot 17$ & $6 \cdot 3$ \\
\hline Fat-free mass & $I \cdot I 49$ & $\div 3 \cdot 5$ & $\mathrm{I} \cdot 88$ & $3 \cdot 2$ \\
\hline Fat-free dry matter & 0.280 & +0.9 & 0.89 & $6 \cdot 1$ \\
\hline Crude protein & 0.230 & +0.7 & 0.67 & $5 \cdot 6$ \\
\hline
\end{tabular}

RSD $=$ residual standard deviation.

The dissectible fat consisted of subcutancous fat and was therefore less than the chemically defined fat which also included intermuscular, intramuscular and intraperitoneal fat. The dissectible fat-free mass was correspondingly heavier than the chemical fat-free mass, but the two were highly cotrelated $(r=0.974)$.

Estimation of body water by $\mathrm{D}_{2} \mathrm{O}$

From the values in Table 2 it can be seen that the mean $\mathrm{D}_{2} \mathrm{O}$ space was $8.5 \%$ greater than the mean weight of EBW but only $2.2 \%$ in excess of that of the TBW. Allowance could be made for these biases by using the regression equations given 
Table 4. Regression equations for estimating, in pigs, the fat content of the body from $\mathrm{D}_{2} \mathrm{O}$ space and live weight jointly

\begin{tabular}{|c|c|c|c|c|c|}
\hline \multirow{3}{*}{$\begin{array}{l}\text { Body component } \\
(\mathrm{kg})\end{array}$} & \multicolumn{5}{|c|}{ Regression equation on $\mathrm{D}_{2} \mathrm{O}$ space $(\mathrm{kg})$ and live wt $(\mathrm{kg})$} \\
\hline & \multicolumn{2}{|c|}{ Regression coefficients } & \multirow[b]{2}{*}{ Intercept } & \multirow[b]{2}{*}{ RSD } & \multirow{2}{*}{$\begin{array}{l}\text { RSD as } \\
\text { percentage } \\
\text { of mean }\end{array}$} \\
\hline & On $\mathrm{D}_{2} \mathrm{O}$ space & On live wt & & & \\
\hline $\begin{array}{l}\text { Dissectible fat } \\
\text { Total lipid }\end{array}$ & $\begin{array}{l}-0.846 \\
-1 \cdot 216\end{array}$ & $\begin{array}{l}+0.714 \\
+0.904\end{array}$ & $\begin{array}{l}-I \cdot 0 \\
+4 \cdot 8\end{array}$ & $\begin{array}{l}1 \cdot 07 \\
1 \cdot 42\end{array}$ & $\begin{array}{l}6 \cdot 0 \\
6 \cdot 7\end{array}$ \\
\hline
\end{tabular}

in Table 3 to estimate EBW and TBW from $\mathrm{D}_{2} \mathrm{O}$ space. TBW is estimated more precisely than is EBW (residual standard deviations 0.9 and $1.2 \mathrm{~kg}$ respectively), which tends to substantiate the findings of a previous study (Houseman, unpublished results) that $\mathrm{D}_{2} \mathrm{O}$ concentration had equilibrated in the fluids of the intestinal tract and bladder as well as in the body fluids.

\section{Estimation of weights of body components from $\mathrm{D}_{2} \mathrm{O}$ space}

Because of the relative constancy of composition of the fat-free body mass it is possible to use regression equations based on $\mathrm{D}_{2} \mathrm{O}$ space to estimate not only water, but also the other components of the body except fat. Table 3 shows equations derived for this purpose from the present results. If account is taken of live weight, fat can also be estimated, in effect by difference. Table 4 gives multiple regressions of fat content on $\mathrm{D}_{2} \mathrm{O}$ space and live weight. The precisions of the estimates from all the regression equations are indicated in absolute terms by the residual standard deviations and as percentages by the corresponding coefficients of variation. Comparisons between these and the standard deviations in Table 2 show how much of the total variation in each measured component of body-weight is associated with variation in $\mathrm{D}_{2} \mathrm{O}$ space (or $\mathrm{D}_{2} \mathrm{O}$ space taken jointly with live weight).

\section{DISCUSSION}

In planning this investigation into the relationships between $\mathrm{D}_{2} \mathrm{O}$ space and the body components of pigs of about bacon weight it was decided to use a range of diets and levels of feeding in order to ensure that the weights of the body components were sufficiently variable to provide a good test of the relationships. The success of the treatments in achieving this may be indicated by quoting the range of fat-free mass (from 50.2 to $69.9 \mathrm{~kg}$ ) and the range of age of the pigs at slaughter (from $\mathrm{I} 53$ to $290 \mathrm{~d}$ ). The mean values obtained on each treatment are of no interest in themselves, but the fattest animals were, as expected, those on high intakes of the low-protein diet. The castrated pigs were on average slightly fatter than the gilts but the difference was not statistically significant. The derivation of relationships between $\mathrm{D}_{2} \mathrm{O}$ space and weights of body components from such diverse animals does not detract from their applicability to more uniform populations. The residual standard deviations given here would remain valid as estimates of the goodness of fit of the relationships.

Study of the ratios given in Table 2 based on the chemical analyses of the carcasses 
shows that, whereas the ratio of total lipid to empty body-weight was extremely variable (coefficient of variation $2 \mathrm{I} \cdot 3 \%$ ), the ratios not involving fat were remarkably constant in view of the nutritional extremes to which the animals had been subjected. In particular, there was a coefficient of variation of only $\mathrm{I} \cdot 3 \%$ for the ratio of EBW to fat-free mass and there was no evidence that this ratio depended on age, on degree of fatness, on fat-free weight itself, or on the sex of the animal. The mean value of $75.6 \%$ for the water content of the fat-free material agrees closely with values obtained in previous studies (Kraybill, Goode, Robertson \& Sloane, I953; Clawson, Sheffy \& Reid, 1955; Gnaedinger, Pearson, Reineke \& Hix, 1963; Reid, Bensadoun, Bull, Burton, Gleeson, Han, Joo, Johnson, McManus, Paladines, Stroud, Tyrrell, Van Niekerk \& Wellington, I968).

The relative constancy of body composition when fat is excluded means that measurements of EBW could be used to derive estimates of other components. For example, fat-free mass $(y, \mathrm{~kg})$ could be estimated from $\mathrm{EBW}(x, \mathrm{~kg})$ with a residual coefficient of variation of $\mathrm{I} \cdot 2 \%$ by the regression equation, $y=\mathrm{I} \cdot 33^{x}-0.350$, based on the present results. More important estimates of the other components could be derived from any measurement, such as $\mathrm{D}_{2} \mathrm{O}$ space, which was itself an estimator of EBW. As can be seen from the residual coefficients of variation in Table 3, these estimates are less precise than the more direct estimates of EBW from $D_{2} \mathrm{O}$ space or of (for example) fat-free mass from EBW.

Although weight of total body lipid is much more variable than that of crude protein in relation to body water, it can be estimated from $\mathrm{D}_{2} \mathrm{O}$ space with almost the same precision (coefficients of variation respectively 6.7 and $5.6 \%$ - Tables 4 and 3 ), provided that account is taken of live weight. In effect the estimate of total lipid is obtained by difference.

The $\mathrm{D}_{2} \mathrm{O}$ dilution technique described here was found to estimate TBW more precisely than EBW, the coefficients of variation being $1 \cdot 9$ and $2 \cdot 7 \%$ respectively. Further investigation showed that the partial correlation coefficient between $\mathrm{D}_{2} \mathrm{O}$ space and bladder water at slaughter (at constant EBW and gut water) was 0.82 , which is highly significant $(P<0.00 \mathrm{I})$, but the corresponding correlation with gut water was not significant. This correlation of 0.82 does not arise from any direct relationship and must therefore indicate a high correlation between the weights of bladder water at slaughter and at the time when the $\mathrm{D}_{2} \mathrm{O}$ measurement was made. The values of bladder water at slaughter had a very skewed distribution, seventeen being between zero and $0.43 \mathrm{~kg}$ and the remaining seven between 0.95 and $2.95 \mathrm{~kg}$. The residual coefficient of variation of EBW could be reduced from $2 \cdot 7$ to $1 \cdot 7 \%$ either by excluding the latter seven pigs from the analysis or by using weight of bladder water at slaughter as a second independent variable in the regression analysis. We conclude that the variation in weight of water in the bladder had an important effect in limiting the precision of estimation of EBW. It is possible that variation in weight of water in the gut may have had a similar effect but that this was not detected because of a low correlation between the weights of gut water at slaughter and at the time of measurement of $\mathrm{D}_{2} \mathrm{O}$ dilution.

The $\mathrm{D}_{2} \mathrm{O}$ space in this study was found on average to be $2 \cdot 2 \%$ greater than the 
measured TBW. This difference would tend to support the suggestions of Krogh $\&$ Ussing (1936), Ussing (1938) and Smith, Trace \& Barbour (1936) that deuterium ions may also exchange with the non-aqueous hydrogen ions of proteins. In a more recent study, Reid, Balch \& Glascock (1958) found that, for tritiated water, exchange with non-aqueous hydrogen ions resulted in an error of $0.5-2 \%$ in the estimation of body water in rabbits. The difference could alternatively arise from inadequacies in the sampling and analytical techniques. Problems of sampling are particularly magnified in this kind of experiment in which the ratio of carcass weight to analytical sample weight can be of the order of 30000 to I.

Thanks are due to the Meat and Livestock Commission for a research scholarship awarded to one of us (RAH) and to Mr Ian Philip for care of the animals.

\section{REFERENCES}

Anderson, D. M. \& Elsley, F. W. H. (1969). F. agric. Sci., Camb. 72, 475.

Bradbury, M. W. B. (I96r). Br. $\mathscr{~}$. Nutr. 15, 177.

Clawson, A. J., Sheffy, B. E. \& Reid, J. T. (1955). F. Anim. Sci. r4, r 22.

Edelman, I. S., Olney, J. M., James, A. H., Brooks, L. \& Moore, F. D. (1952). Science, N. Y. Ix5, 447.

Foot, J. Z. \& Greenhalgh, J. F. D. (I 970). Br. F. Nutr. 24, 8I 5.

Gnaedinger, R. H., Pearson, A. M., Reineke, E. P. \& Hix, V. M. (I963). F. Anim. Sci. 22, 495.

Groves, T. D. D. \& Wood, A. S. (1965). Can. F. Anim. Sci. 45, 8.

Hytten, F. E., Taggart, N., Billewicz, W. Z. \& Jason, A. C. (1962). Physics Med. Biol. 6, 4I5.

Hytten, F. E., Thomson, A. M. \& 'Taggart, N. (1966). F. Obstet. Gynaec, Br. Commonz. 73, 553.

Kraybill, H. F., Goode, E. R., Robertson, R. S. B. \& Sloane, H. S. (1953). F. appl. Physiol. 6, 27.

Krogh, A. \& Ussing, H. H. (1936). Skand. Arch. Physiol. 75, 90.

Reid, J. T., Balch, C. C. \& Glascock, R. F. (I958). Br. F. Nutr. 12, 43.

Reid, J. T., Bensadoun, A., Bull, L. S., Burton, J. H., Gleeson, P. A., Han, I. K., Joo, Y. D., Johnson, D. E., McManus, W. R., Paladines, O. L., Stroud, J. W., Tyrrell, H. F., Van Niekerk, B. D. H. \& Wellington, G. W. ( ( 968). Publs natn. Res. Coun., Wash. no. I 598.

Schloerb, P. R., Friis-Hansen, B. J., Edelman, I. S., Sheldon, D. B. \& Moore, F. D. (195 ). F. Lab. clin. Med. 37, 653.

Schloerb, P. R., Friis-Hansen, B. J., Edelman, I. S., Solomon, A. K. \& Moore, F. D. (1950). F. clin. Invest. 29, 1296.

Smith, P. K, , Trace, J. \& Barbour, H. G. (1936). F. biol. Chem. II6, 37 I.

Stevens, W. H. \& Thurston, W. (1954). Min. Rep. Atomic Energy of Canada Ltd no. 295. (Reprinted x960.)

Turner, M. D., Neely, W. A. \& Hardy, J. D. (1960). \%. appl. Physiol. 15, 309.

Ussing, H. H. (1938). Skand. Arch. Physiol. 78, 225. 